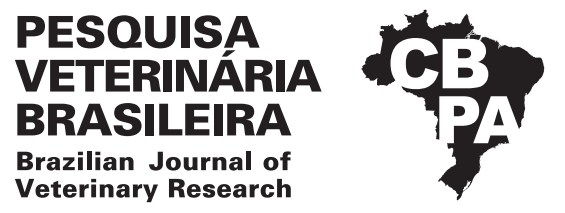

Pesq. Vet. Bras. 39(12):983-988, December 2019 DOI: 10.1590/1678-5150-PVB-6077

Veterinary Researc

ISSN 0100-736X (Print)

ISSN 1678-5150 (Online)

\title{
Oral trichomoniasis in raptors in Southern Brazil ${ }^{1}$
}

\author{
Joanna V.Z. Echenique ${ }^{2,3}$ (D), Mauro P. Soares ${ }^{3^{*}}$ (D), Mirian Bruni ${ }^{4}$, Nara Amélia Farias ${ }^{4}$, \\ Valéria D. Moretti ${ }^{5}$, Paulo M. Bandarra ${ }^{5}$, Ana Paula N. Albano ${ }^{6}$ \\ and Ana Lucia Schild ${ }^{3}$
}

\begin{abstract}
Echenique J.V.Z., Soares M.P., Bruni M., Farias N.A., Moretti V.D., Bandarra P.M., Albano A.P.N. \& Schild A.L. 2019. Oral trichomoniasis in raptors in Southern Brazil. Pesquisa Veterinária Brasileira 39(12):983-988. Laboratório Regional de Diagnóstico, Faculdade de Veterinária, Universidade Federal de Pelotas, Campus Capão do Leão s/n, Pelotas, RS 96010-900, Brazil. E-mail: gmpsoares@gmail.com

A retrospective study of oral trichomoniasis cases in raptors was carried out at "Laboratório Regional de Diagnóstico" of "Faculdade de Veterinária" of "Universidade Federal de Pelotas" (LRD-UFPel) from December 2014 to August 2017. Seven necropsy reports were reviewed. All raptors including Falconiformes and Strigiformes orders were from periurban zones. Four birds were adults, and there was no apparent sex predisposition. Clinical signs included dysphagia, regurgitation, and anorexia. Gross lesions were characterized by multifocal yellow to coalescent caseous nodules adhered to the oral cavity, which extended to the entrance of the esophagus. Microscopically, the lesions were characterized by severe focally extensive heterophilic granulomatous stomatitis. Trichomonas gallinae was isolated in modified Diamond medium of all samples collected from birds. It is believed the transmission occurred by the predation of domestic pigeons (Columbia livia domestica) contaminated with T. gallinae that agglomerate in patios of grain processing complexes.
\end{abstract}

INDEX WORDS: Oral trichomoniasis, raptors, Brazil, Trichomonas gallinae, Caracara plancus, Asio clamator, oral trichomoniasis, spillover, wildlife animals.

RESUMO.- [Tricomoníase oral em rapinantes no sul do Brasil.] Foi realizado um estudo retrospectivo de casos de tricomoníase oral em rapinantes recebidos no Laboratório Regional de Diagnóstico da Faculdade de Veterinária da Universidade Federal de Pelotas (LRD-UFPel) no período de dezembro de 2014 a agosto de 2017. Foram revisados os protocolos de necropsia encontrando-se sete casos. Os animais eram todos de zonas periurbanas e foram afetadas a ordem Falconiformes e a ordem Strigiformes. Das aves afetadas

\footnotetext{
${ }^{1}$ Received on May 23, 2019.

Accepted for publication on July 10, 2019.

${ }^{2}$ Graduate Program in Veterinary, Faculdade de Veterinária (FV), Universidade Federal de Pelotas (UFPel), Campus Capão do Leão s/n, Pelotas, RS 96010-900, Brazil.

${ }^{3}$ Laboratório Regional de Diagnóstico, Faculdade de Veterinária (FV), Universidade Federal de Pelotas (UFPel), Campus Capão do Leão s/n, Pelotas, RS 96010-900. *Corresponding author: gmpsoares@gmail.com

${ }^{4}$ Departamento de Microbiologia e Parasitologia, Instituto de Biologia, Universidade Federal de Pelotas (UFPel), Campus Capão do Leão s/n, Pelotas, RS 96010-900.

${ }^{5}$ Núcleo de Reabilitação da Fauna Silvestre, Universidade Federal de Pelotas (UFPel), Campus Capão do Leão s/n, Pelotas, RS 96010-900.

${ }^{6}$ Hospital de Clínicas Veterinária, Departamento de Clínica Veterinária, Faculdade de Veterinária (FV), Universidade Federal de Pelotas (UFPel), Campus Capão do Leão s/n, Pelotas, RS 96010-900.
}

4/7 eram adultas e não houve aparente predisposição por sexo. Os sinais clínicos incluíram disfagia, regurgitação e anorexia. As lesões se caracterizaram por nódulos amarelados multifocais a coalescentes aderidos a cavidade oral, que se estendiam até a entrada do esôfago. Histologicamente as lesões caracterizaram-se por estomatite heterofílica granulomatosa focalmente extensiva acentuada. Foi isolado em meio Diamond modificado Trichomonas gallinae de todas as amostras coletadas das aves. Acredita-se que a fonte de transmissão tenha ocorrido a partir da predação por estes rapinantes de pombas domésticas (Columbia livia domestica) portadoras com T. gallinae que se aglomeram em pátios de complexos de beneficiamento de grãos.

TERMOS DE INDEXAÇÃO: Tricomoníase oral, rapinantes, Brasil, Trichomonas gallinae, Caracara plancus, Asio clamator, tricomoníase oral, spillover, aves silvestres.

\section{INTRODUCTION}

Oral trichomoniasis in prey is a cosmopolitan disease that has been described in several bird orders from various countries (Peppler \& Oettié 1992, McKeon et al. 1997, Krone et al. 2005) and islands (Harmon et al. 1987, Padilla et al. 2004, 
Forzán et al. 2010). In Brazil, the disease has been described in birds of prey in São Paulo (Joppert 2007) and in Minas Gerais in Ramphastidae family, birds of prey, and passerines (Ecco et al. 2012, Andery et al. 2013). In Rio Grande do Sul there are reports of trichomoniasis in domestic pigeons (Tasca \& De Carli 1999), and cases in prey are not described. Studies have shown that it is a disease with high potential for dissemination and a severe factor in decreasing wild bird populations worldwide. This is mainly due to the severity of the lesions and the destruction of oral cavity tissues and surrounding areas (Cole 1999, Forrester \& Foster 2008). The disease is caused by Trichomonas gallinae, a mobile protozoan, which has four typical free flagella arising from a basal granule at the anterior pole of the organism and an undulating membrane (Stabler 1941, BonDurant \& Honigberg 1994). This protozoan has a wide variety of hosts (Forrester \& Foster 2008) and the domestic pigeon (Columba livia domestica) is the main reservoir and source of infection for birds of prey and can be a limiting factor for the conservation of these species (Tasca \& De Carli 1999). T. gallinae has a direct life cycle, having no cyst or resistance form, and can be transmitted from parents to nestlings by regurgitation (crop milk), infected feeders and/ or acquired in contaminated water (Kocan 1969, De Carli et al. 1979, Cole 1999, Purple \& Gerhold 2015).

Birds of prey are carnivorous and comprise several orders including: Accipitriforms orders represented by hawks and eagles such as Parabuteo unicincus (Harris's hawk) and Rupornis magnirostris (Roadside hawk); Falconiformes, with 63 species that are mainly represented by "Carcarás" (genera Daptrius, Milvalgo and Caracara); and Strigiformes which comprises owls and has 223 described species (Piacentini et al. 2015). Birds of prey can be found in Brazilian biomes, are often submitted in wildlife rehabilitation centers politraumatized (Joppert 2007). In addition, these birds are affected by a wide variety of diseases, including oral trichomoniasis (Work \& Hale 1996, Joppert 2007, Park 2011). This disease has been described in wildlife rehabilitation centers, especially affecting birds from periurban areas, with a $10 \%$ prevalence rate (Joppert 2007, Ecco et al. 2012). In private clinics in the Middle East, in falconry raptors the disease prevalence ranges from $8 \%$ to over 30\% (Samour et al. 1995, Bailey et al. 1996). Cases of oral trichomoniasis in free-range birds of prey have not been described in Rio Grande do Sul State.

The aim of the present study was to describe the clinical, epidemiological, gross and histological aspects of oral trichomoniasis in free range birds of prey submitted for necropsy at Regional Diagnostic Laboratory of the Veterinary Faculty of the "Universidade Federal de Pelotas" (LRD-UFPel). As well suggest the form of contamination of these birds in the southern region of Rio Grande do Sul.

\section{MATERIALS AND METHODS}

From 2014 to 2017, seven cases of birds of prey suspected of oral trichomoniasis were received at the LRD-UFPel. These birds were sent from December 2014 to August 2017 by the Wildlife Rehabilitation Center (NURFS-CETAS-UFPel), and the clinical records were obtained with the responsible veterinarian. All birds were necropsied and samples from all organs were collected and fixed in $10 \%$ buffered formalin, routinely processed for histology and stained with hematoxylin and eosin (HE). Fragments of tongue and palate lesions were stained with periodic acid-Schiff (PAS) and Masson's trichrome (MT). Two swab samples were collected from oral lesions for parasitological analysis. One was and immediately examined between slide and coverslip with physiological solution in light microscope. The second sample was collected for parasitological culture and inoculated in modified Diamond media. The samples were inoculated in a falcon tube containing bovine fetal serum, plus $0.3 \mathrm{mg} / \mathrm{mL}$ meropenem and $0.2 \mathrm{mg} / \mathrm{mL}$ amphotericin $\mathrm{B}$ and incubated at $37^{\circ} \mathrm{C}$ for 24 to 48 hours (Diamond 1957). The tube was centrifuged at $1500 \mathrm{rpm}$ for 10 minutes, and an aliquot of the pellet was placed between slide and coverslip for viewing the trophozoites under light microscopy.

\section{RESULTS}

\section{Clinical signs and epidemiology}

From December 2014 to August 2017 were submitted seven raptors from six different species, belonging to two families, Strigidae (4/7) and Falconidae (3/7). The birds came from periurban areas of Rio Grande, Pelotas, and Camaquã municipalities and were sent submitted to NURFS-CETAS-UFPel, presenting oral lesions compatible with oral trichomoniasis. The bird's category was juvenile (3/7), and adult (4/7) with three males and four females. The cases were registered between October and February, and one case was observed in August. The disease progressed from one to nine days. One bird was dead on arrival, and two others were euthanized due to severity lesions and poor prognosis. The summary of epidemiological data is presented in Table 1 . All seven birds had poor body condition being $4 / 7$ lean and $3 / 7$ cachectic. Clinical signs observed in all seven birds were characterized by dysphagia, regurgitation, and anorexia. Signs of respiratory distress and rales, orthopnea position, and open beak were observed in one bird. In three birds, the feathers were covered with regurgitation remains.

\section{Pathology}

All animals received were presenting the chronic form of the disease, and there were lesions in the oral cavity that ranged from small nodules to yellowish plaques measuring aproximally $5 \mathrm{~mm}$, to large, well-adhered, multifocal nodules that occupied almost the entire palate. (Fig.1). Also, brownish velvet plaque lesions were observed. These lesions could be observed on the hard palate and choanae. In two birds, part of the jugal and maxillary bones was affected, with tissue loss and necrosis (Fig.2). In Bird Number 5 was also observed bone involvement with sinusitis and impairment of the cribriform laminae.

Histologically the lesions were characterized by multifocal to coalescent severe heterophilic ulcerative stomatitis and/or esophagitis. It was observed a hipeosinophilic center surrounded by macrophages and giant cells, degenerated heterophils and lymphocytes with a discrete fibroblast and connective tissue proliferation within the peripheral areas. Around the granulomas, there was also an abundant inflammatory infiltrate of lymphocytes, plasmocytes, and macrophages associated with necrotic areas (Fig.3). In some fragments, it was possible to observe hyperplasia of the epithelium adjacent to the lesions. In PAS staining it was not possible to observe the trophozoites. In cases where bone involvement was observed, there was bone loss, necrotizing osteomyelitis, osteolysis, and bone remodeling with areas of fibrosis best observed on MT staining. 
Table 1. Epidemiological data and macroscopic lesions of the eight cases of oral trichomoniasis in prey received at LRD-UFPel from 2014 to 2017

\begin{tabular}{|c|c|c|c|c|c|c|c|}
\hline Case no. & $\begin{array}{l}\text { Common } \\
\text { name/ } \\
\text { species }\end{array}$ & Date & $\begin{array}{l}\text { Municipality } \\
\text { of origin }\end{array}$ & $\begin{array}{l}\text { Gender and } \\
\text { age }\end{array}$ & $\begin{array}{l}\text { Clinical } \\
\text { course }\end{array}$ & Macroscopic lesions & Concomitant diseases \\
\hline 1 & $\begin{array}{l}\text { American } \\
\text { kestrel/ } \\
\text { Falco } \\
\text { sparverius }\end{array}$ & $12 / 2014$ & Pelotas & Adult female & 1 day & $\begin{array}{l}\text { Extensive yellow erosive lesion } \\
\text { from the tip of the beak until } \\
\text { the jugal arch on the lower right } \\
\text { side of the oral cavity affecting } \\
\text { only soft tissue. Near the jugal } \\
\text { arch the subcutaneous tissue } \\
\text { is swollen forming a } 1.5 \mathrm{~cm} \\
\text { diameter nodule. }\end{array}$ & No \\
\hline 2 & $\begin{array}{l}\text { Striped } \\
\text { owl/ } \\
\text { Asio } \\
\text { clamator }\end{array}$ & $2 / 2015$ & Camaquã & $\begin{array}{l}\text { Young } \\
\text { female }\end{array}$ & $\begin{array}{c}\text { Arrived } \\
\text { dead }\end{array}$ & $\begin{array}{l}\text { Yellowish nodule approximately } \\
1 \mathrm{~cm} \text { in diameter adhered to } \\
\text { the soft palate, which partially } \\
\text { obstructed the glottis. }\end{array}$ & $\begin{array}{l}\text { Dislocation of the right } \\
\text { tibiotarsometatarsal joint } \\
\text { with associated myiasis }\end{array}$ \\
\hline 3 & $\begin{array}{l}\text { American } \\
\text { barn owl/ } \\
\text { Tyto furcata }\end{array}$ & $12 / 2016$ & Camaquã & Adult male & 1 day & $\begin{array}{l}\text { Friable yellow-brown plaque } \\
\text { extending across the soft palate } \\
\text { and half of the hard palate on } \\
\text { the left side only. Multifocal } \\
\text { necrotic nodules with caseous } \\
\text { appearance, whitish and soft } \\
\text { to the cut, measuring } 3 \mathrm{~mm} \text { in } \\
\text { diameter around the tongue and } \\
\text { ulcers in the right hard palate } \\
\text { about } 5 \mathrm{~mm} \text { in diameter. }\end{array}$ & $\begin{array}{c}\text { Severe multifocal } \\
\text { pulmonary aspergillosis }\end{array}$ \\
\hline 4 & $\begin{array}{l}\text { Southern } \\
\text { caracara/ } \\
\text { Caracara } \\
\text { plancus }\end{array}$ & $2 / 2016$ & Rio Grande & Young male & 4 days & $\begin{array}{l}5 \mathrm{~cm} \text { yellowish nodule extending } \\
\text { from the right jugal arch to } \\
\text { the mandible branch. Velvety } \\
\text { necrotic plaques about } 7 \mathrm{~mm} \text {, } \\
\text { diffuse around the enlarged } \\
\text { tongue. }\end{array}$ & No \\
\hline 5 & $\begin{array}{l}\text { Striped } \\
\text { owl/ } \\
\text { Asio } \\
\text { clamator* }\end{array}$ & $10 / 2016$ & Pelotas & $\begin{array}{l}\text { Adult } \\
\text { female }\end{array}$ & 0 days & $\begin{array}{l}\text { Caseous, yellow oral plaque } \\
\text { lesion occupying the right half } \\
\text { of the hard palate with bone } \\
\text { involvement and extended to the } \\
\text { esophageal entrance. There was } \\
\text { necrosis of the cribriform skull } \\
\text { blades, sinusitis and palpebral } \\
\text { edema. }\end{array}$ & No \\
\hline 6 & $\begin{array}{l}\text { Southern } \\
\text { caracara/ } \\
\text { Caracara } \\
\text { plancus }\end{array}$ & $11 / 2016$ & Rio Grande & Young male & 7 days & $\begin{array}{l}\text { Ulcerative yellow lesion } \\
\text { affecting the mandible, maxilla, } \\
\text { pterygoid region and palatal } \\
\text { region with bone involvement of } \\
\text { the jugal arch and exposure of } \\
\text { the right choanae. }\end{array}$ & $\begin{array}{c}\text { Marked diffuse fibrin } \\
\text { heterophilic pneumonia }\end{array}$ \\
\hline 7 & $\begin{array}{l}\text { Great horned } \\
\text { owl/ Bubo } \\
\text { virginianus }\end{array}$ & $8 / 2017$ & Rio Grande & Adult female & 0 days & $\begin{array}{l}\text { Yellowish plaque affecting only } \\
\text { the left side, affecting two thirds } \\
\text { of the hard palate and the entire } \\
\text { soft palate forming a large mass } \\
\text { that caused obstruction of the } \\
\text { esophageal entrance. }\end{array}$ & No \\
\hline
\end{tabular}

* Animals arrived at NURFS with extensive lesions and were euthanized.

\section{Parasitology}

On direct examination, no parasites were found. In the culture of the lesions, mobile organisms were observed 24 hours after incubation. The identification of Trichomonas gallinae was performed by observing the morphological aspects described by Stabler (1941) and Abraham \& Honigberg (1964). The organisms had a piriform shape, rounded at both ends with $10.1-14.8 \mu \mathrm{m}$ in length $\times$ 7.3-8.0 $\mu \mathrm{m}$ wide, well-developed undulating membrane, not reaching the posterior end of the parasite, with accessory filament, clearly evident axostyle about $1 / 3$ the size of the cell and exposed at the posterior portion; four uneven anterior flagella, absence of the fifth free flagella in the posterior portion and oval nucleus (Fig.4). 


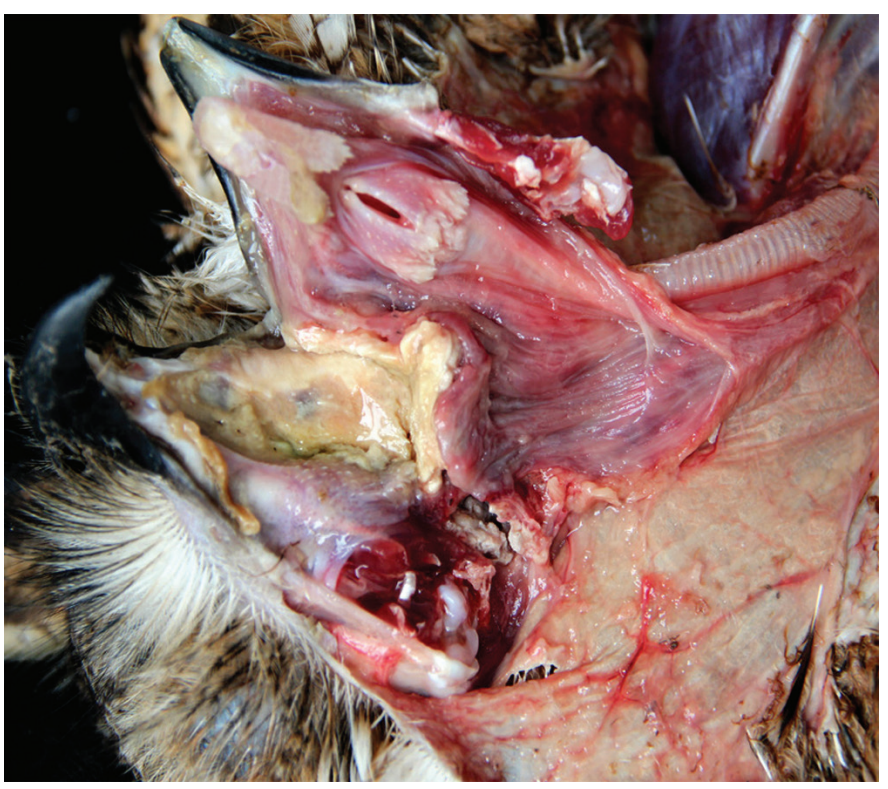

Fig.1. Bird Number 7. Bubo virginianus. Oral cavity. Caseous yellowish focally extensive plaque, occupying the left half of the hard palate, compromising the choanae and extending to the esophageal entrance.

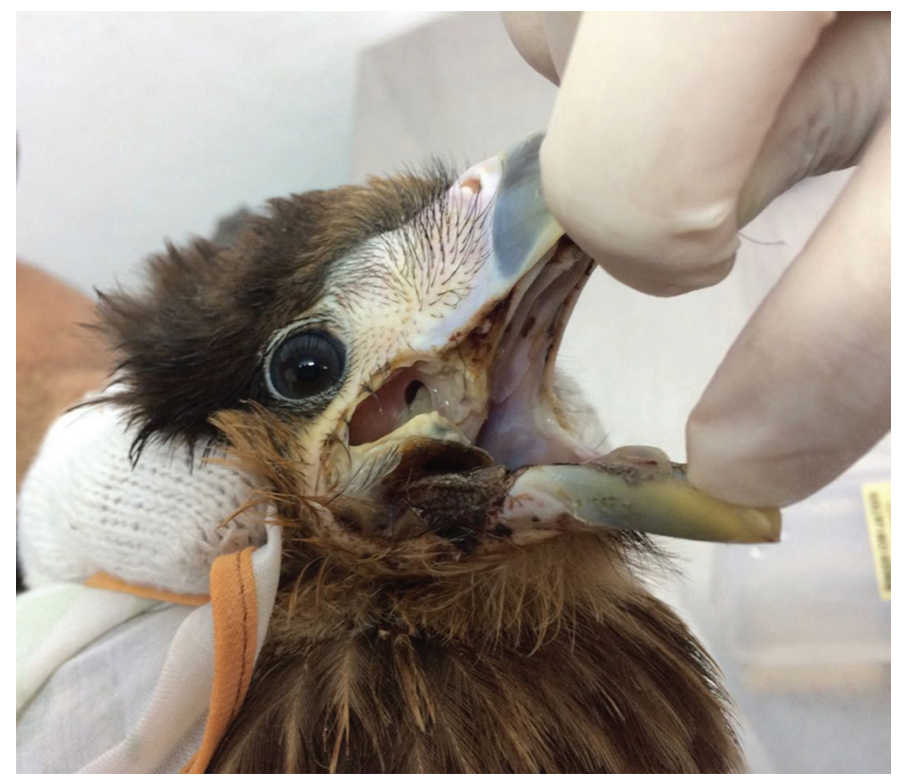

Fig.2. Bird Number 6. Caracara plancus. Beak and oral cavity. Ulcerative yellow- brown lesion with detachment and jugal bone, mandible, maxilla, pterygoid region, and palatal region necrosis with exposure of the bottom of the eye.

\section{DISCUSSION}

The diagnosis of oral trichomoniasis by Trichomonas gallinae was based in clinical signs, macroscopic and histological lesions and morphological identification of the agent described by other authors (Stabler 1941, Abraham \& Honigberg 1964).

Birds with trichomoniasis in the present study presented variations in severity and lesions extension, and in two cases, there was involvement of the esophagus and crop. It has been reported that the disease is more severe in young

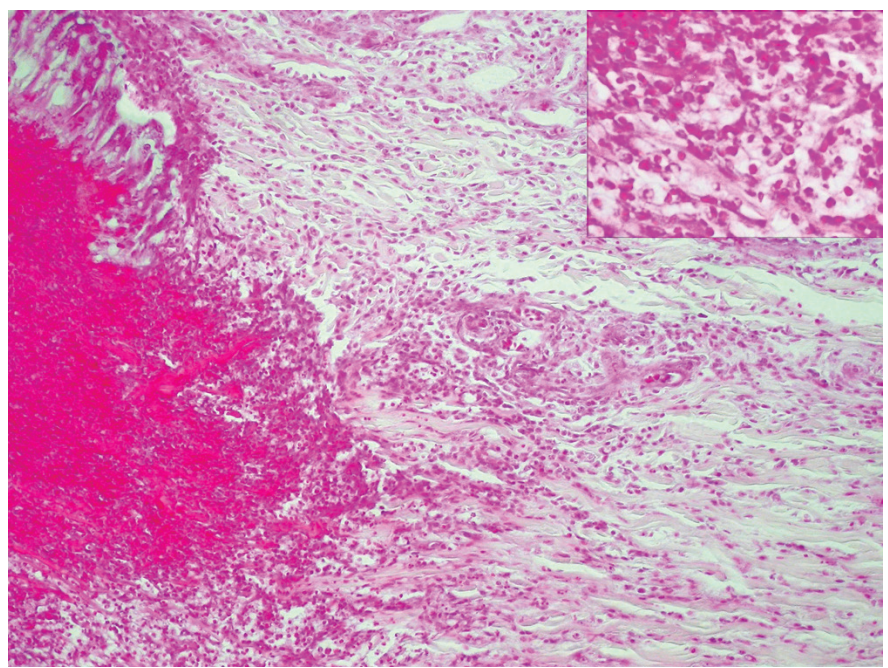

Fig.3. Bird Number 6. Caracara plancus. Hard palate. Hypereosinophilic area surrounded by macrophages, giant cells with discrete fibroblast proliferation (upper left) and inflammatory infiltrate containing degenerate heterophils and macrophages in the periphery and center of the tissue. HE, obj.10x. Inset: more massive enlargement of the lower-left corner where degenerate heterophils and macrophages are observed. HE, obj.40x.

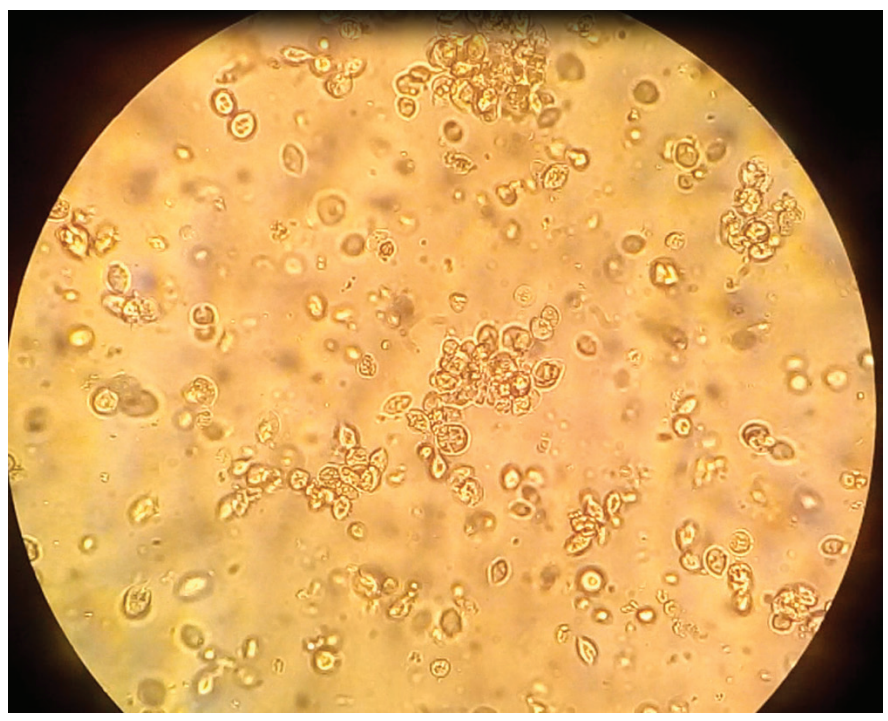

Fig.4. Bird Number 3. Tyto furcata. Diamond media, direct smear, 100x. Innumerous trophozoites of Trichomonas gallinae after 24 hours incubation. It can be notices the pyriform and/or rounded shaped organisms.

animals (Cole 1999). In this study, this fact can be observed and confirmed since $3 / 7$ were adult birds, and juvenile birds had more severe lesions. On the other hand, it has also been mentioned that the lesions are even more severe in birds from naïve populations. This fact is highlighted by nearby extinction of islands endemic bird populations due to introduction of T. gallinae reservoir species (Rosenfield et al. 2002, Park 2011). In the present report, the affected animals probably belonged to disease-free populations and/or were 
immunosuppressed due to lack of food. The hypothesis of immunosuppression is reinforced by the occurrence of a case of aspergillosis among the affected prey.

The cases occurred mainly in the warmer months (from October to February). It has been suggested that high temperatures associated with accumulated moisture in grains dispersed in grain plants yards may be an initial source of contamination and spread among domestic pigeons inhabiting periurban areas (Purple \& Gerhold 2015) and consequently contamination of their predators.

Histologically in all birds, coalescing multifocal granulomatous heterophilic ulcerative stomatitis was observed and only two animals had bone involvement. Although PAS staining is recommended (Mesa et al. 1961, Narcisi et al. 1991), in the present study there was no positive histochemical staining for the agent, as found by other authors (Amin et al. 2011). Other special stains can also be used to facilitate visualization of T. gallinae in tissues, such as Warthin-Starry staining (Araujo et al. 2018). Direct examination of the lesions was also not efficient in identifying the agent after swab collection from the birds' oral cavity. The Diamond culture was the most efficient diagnostic method (Boal et al. 1998, Boal \& Mannan 1999, Amin et al. 2014). This media was developed for the detection of Trichomonas sp. in women and has been used as the gold diagnostic standard for the identification of this parasite (Diamond 1957).

Oral trichomoniasis is considered an emerging disease in many parts of the world and is affecting wild species in which there are no previous reports of the disease, characterizing the spillover (Bunbury et al. 2007, Forzán et al. 2010, Lawson et al. 2011). The disease should be differentiated from oral candidiasis, fowlpox (pox virus) and hypovitaminosis A, since in these diseases oral lesions are similar to those described in trichomoniasis (Cole 1999, Joppert 2007, McDougald 2013).

In the present study, it is believed that the affected raptors were contaminated by their prey (domestic pigeons). Most came from the Rio Grande municipality, where, due to the existence of one of the largest bulk carriers complex in Brazil, there is a large agglomeration of birds, including the domestic pigeon; and from Camaquã and Pelotas where there are grain-processing complexes. All animals came from those periurban areas where those plants are located. Although pigeons are not normal food items in raptors diet, it is likely that due to insufficiency of food because of environmental degradation, these raptors are changing their consumption habits and may have started to prey pigeons, which are important in the T. gallinae maintenance life cycle as reservoirs (Tasca \& De Carli 1999). The pigeons may feed on the loose grains within this area. T. gallinae protozoan has already been isolated from wet grains, becoming viable for up to five days (Kocan 1969, Purple \& Gerhold 2015), which would lead to contamination of pigeons and maintain the agent in the environment and its life cycle.

Besides, the all raptors present in this study had a low body condition and half had associated diseases, which probably reduced their hunting capacity of birds, forcing them to look for easy and probably infected prey. Some studies have shown that domestic and wild Columbiformes harboring T. gallinae have lower body condition, even clinically healthy, making them more susceptible to predation (Villanúa et al. 2006). In other countries the source of pigeon contamination are garden feeders and waterers, which lead to bird crowding (Cole 1999, Lawson et al. 2011, 2012). Four female birds were affected in the reproductive season (spring/summer). This can be explained because these birds have a tendency to look for easier preys in order to no stay away from the nest.

\section{CONCLUSIONS}

Trichomoniasis occurs in the southern region of Rio Grande do Sul in different species of raptors and its contamination is probably due to the predation of reservoir pigeons that feed on loose grains in the bulk terminals of periurban areas of the state municipalities of Camaquã, Pelotas and Rio Grande and can be considered a spillover event. The disease affected both young and adult animals and was characterized by all cases of a long evolution with granulomatous lesions.

It was also concluded that PAS is not suitable for staining the agent, and Trichomonas gallinae proliferates in a modified Diamond culture media.

Conflict of interest statement. The authors declare that they have no conflict of interest.

\section{REFERENCES}

Abraham R. \& Honigberg B.M. 1964. Structure of Trichomonas gallinae (Rivolta). J. Parasitol. 50(5):608-619. <http://dx.doi.org/10.2307/3276114> <PMid:14215477>

Amin A., Liebhart D., Weissenböck H. \& Hess M. 2011. Experimental infection of turkeys and chickens with a clonal strain of Tetratrichomonas gallinarum induces a latent infection in the absence of clinical signs and lesions. J. Comp Pathol. 144(1):55-62. <http://dx.doi.org/10.1016/j.jcpa.2010.06.002> <PMid:20708742>

Amin A., Bilic I., Liebhart D. \& Hess M. 2014. Trichomonads in birds-a review. Parasitology 141(6):733-747. <http://dx.doi.org/10.1017/ S0031182013002096><PMid:24476968>

Andery D.A., Ferreira Junior F.C., Araújo A.V., Vilela D.A.R., Marques M.V.R., Marin S.Y., Horta R.S., Ortiz M.C., Resende J.S. \& Martins N.R.S. 2013. Health assessment of raptors in triage in Belo Horizonte, MG, Brazil. Braz. J. Poult. Sci. 5(3):169-286. <http://dx.doi.org/10.1590/S1516-635X2013000300012>

Araujo J.L., Plumlee Q., Kleinschmidt L., Hoppes S.M., Sharman M. \& Rech R. 2018. Pathology in practice. JAVMA 253(11):1421-1424. <http://dx.doi org/10.2460/javma.253.11.1421 > <PMid:30451622>

Bailey T.A., Samour J.H., Naldo J., Howlett J.C. \& Tarik M. 1996. Causes of morbidity in bustards in the United Arab Emirates. Avian Dis. 40(1):121 129. <http://dx.doi.org/10.2307/1592381> <PMid:8713025>

Boal C.W. \& Mannan R.W. 1999. Comparative breeding ecology of Cooper's hawks in urban and exurban areas of southeastern Arizona. J. Wildl. Manag. 63(1):77-84. <http://dx.doi.org/10.2307/3802488>

Boal C.W., Mannan R.W. \& Hudelson K.S. 1998. Trichomoniasis in Cooper's hawks from Arizona. J. Wildl. Dis. 34(3):590-593. <http://dx.doi. org/10.7589/0090-3558-34.3.590><PMid:9706569>

BonDurant R.H. \& Honigberg B.M. 1994. Trichomonads of veterinary importance p.111-206. In: Kreier J. (Ed.), Parasitic Protozoa. Academic Press, New York <http://dx.doi.org/10.1016/B978-0-12-426019-1.50007-6>

Bunbury N., Jones C.G., Greenwood A.G. \& Bell D.J. 2007. Trichomonas gallinae in Mauritian columbids: implications for an endangered endemic. J. Wildl Dis. 43(3):399-407. <http://dx.doi.org/10.7589/0090-3558-43.3.399> <PMid:17699078>

Cole R.A. 1999. Trichomoniasis, p.201-206. In: Friend M. \& Franson J.C. (Eds), Field Manual of Wildlife Diseases, General Field Procedures and Diseases of Birds. United States Geological Survey, Madison, Wisconsin. 
De Carli G.A., Pansera M.C.G. \& Guerrero J. 1979. Trichomonas gallinae (Rivolta, 1978) Stabler, 1938, from the upper digestive tract of the common pigeon, Columba livia, the State of Rio Grande do Sul - first register. Acta Biol. Leopoldensia 1:85-95.

Diamond L.S. 1957. The establishment of various Trichomonas of animals and man in axenic cultures. J. Parasitol. 43(4):488-490. <http://dx.doi. org/10.2307/3274682><PMid:13463700>

Ecco R., Preis I.S., Vilela D.A., Luppi M.M., Malta M.C., Beckstead R.B., Stimmelmayr R. \& Gerhold R.W. 2012. Molecular confirmation of Trichomonas gallinae and other parabasalids from Brazil using the 5,8S and ITS- 1 rRNA regions. Vet. Parasitol. 190(1/2):36-42. <http://dx.doi.org/10.1016/j. vetpar.2012.05.029><PMid:22749289>

Forrester D.J. \& Foster G.W. 2008. Trichomonosis, p.120-153. In: Atkinson C.T., Thomas N.J. \& Hunter D.B. (Eds), Parasitic Diseases of Wild Birds. Wiley-Blackwell, Ames, IA.

Forzán M.J., Vanderstichel R., Melekhovets Y.F. \& McBurney S. 2010. Trichomoniasis in finches from the Canadian Maritime provinces - an emerging disease. Can. Vet. J. 51(4):391-396. <PMid:20592828>

Harmon W.M., Clark W.A., Hawbecker A.C. \& Stafford M. 1987. Trichomonas gallinae in columbiform birds from the Galapagos Islands. J. Wildl. Dis. 23(3):492-494. <http://dx.doi.org/10.7589/0090-3558-23.3.492> $<$ PMid:3625913>

Joppert A.M. 2007. Estudo prospectivo das causas de morte de Falconiformes e Strigiformes de vida livre no município de São Paulo. Doctoral Dissertation, Graduate Program in Experimental and Comparative Pathology, Faculdade de Veterinária e Zootecnia, Universidade de São Paulo, São Paulo. 199p.

Kocan R.M. 1969. Various grains and liquid as potential vehicles of transmission for Trichomonas gallinae. Bull. Wildl. Dis. Assoc. 5(3):148-149. <http:// dx.doi.org/10.7589/0090-3558-5.3.148> <PMid:5817771>

Krone O., Altenkamp R. \& Kenntner N. 2005. Prevalence of Trichomonas gallinae in northern goshawks from the Berlin area of northeastern Germany. J. Wildl. Dis. 41(2):304-309. <http://dx.doi.org/10.7589/00903558-41.2.304><PMid:16107664>

Lawson B., Robinson R.A., Colvile K.M., Peck K.M., Chantrey J., Pennycott T.W., Simpson V.R., Toms M.P. \& Cunningham A.A. 2012. The emergence and spread of finch trichomonosis in the British Isles. Philos. Trans. R. Soc. Lond. B, Biol. Sci. 367(1604):2852-2863. <http://dx.doi.org/10.1098/ rstb.2012.0130><PMid:22966140>

Lawson B., Robinson R.A., Neimanis A., Handeland K., Isomursu M., Agren E.O., Hamnes I.S., Tyler K.M., Chantrey J., Hughes L.A., Pennycott T.W., Simpson V.R., John S.K., Peck K.M., Toms M.P., Bennett M., Kirkwood J.K. \& Cunningham A.A. 2011. Evidence of spread of the emerging infectious disease, finch trichomonosis, by migrating birds. EcoHealth 8(2):143-153. <http://dx.doi.org/10.1007/s10393-011-0696-8> <PMid:21935745>

McDougald L.R. 2013. Protozoal Infections: trichomoniasis, p.1179-1181. In: Nair V., Suarez D.L., Nolan L.K., McDougald L.R., Glisson J.R. \& Swayne D.E. (Eds), Diseases of Poultry. 13th ed. Iowa State University Press, Ames, IA.

McKeon T., Dunsmore J. \& Raidal S.R. 1997. Trichomonas gallinae in budgerigars and columbid birds in Perth, Western Australia. Aust. Vet. J.
75(9):652-655. <http://dx.doi.org/10.1111/j.1751-0813.1997.tb15363. $\mathrm{x}><$ PMid:9325543>

Mesa C., Stabler R. \& Berthrong M. 1961. Histopathological changes in the domestic pigeon infected with Trichomonas gallinae (Jones' barn strain). Avian Dis. 5(1):48-60. <http://dx.doi.org/10.2307/1587659>

Narcisi E.M., Sevoian M. \& Honigberg B.M. 1991. Pathologic changes in pigeons infected with a virulent Trichomonas gallinae strain (Eiberg). Avian Dis. 35(1):55-61. <http://dx.doi.org/10.2307/1591295><PMid:2029262>

Padilla L.R., Santiago-Alarcon D., Merkel J., Miller R.E. \& Parker P.G. 2004. Survey for Haemoproteus spp., Trichomonas gallinae, Chlamydophila psittaci, and Salmonella spp. in Galapagos Islands columbiformes. J. Zoo Wildl. Med. 35(1):60-64. <http://dx.doi.org/10.1638/03-029><PMid:15193075>

Park F.J. 2011. Avian trichomoniasis: a study of lesions and relative prevalence in a variety of captive and free-living bird species as seen in an Australian avian practice. Aust. Vet. J. 89(3):82-88. <http://dx.doi. org/10.1111/j.1751-0813.2010.00681.x><PMid:21323655>

Peppler D. \& Oettié E.E. 1992. Trichomonas gallinae in wild raptors on the Cape Peninsula. S. Afr. J. Wildl. Res. 22(3):87-88.

Piacentini V.D., Aleixo A., Agne C.E., Maurício G.N., Pacheco J.F., Bravo G.A., Brito G.R., Naka L.N., Olmos F., Posso S. \& Silveira L.F. 2015. Annotated checklist of the birds of Brazil by the Brazilian Ornithological Records Committee/Lista comentada das aves do Brasil pelo Comitê Brasileiro de Registros Ornitológicos. Revta Bras. Ornitol. 23(2):90-298.

Purple K.E. \& Gerhold R.W. 2015. Persistence of two Isolates of Trichomonas gallinae in simulated bird baths with and without organic material. Avian Dis. 59(4):472-474. <http://dx.doi.org/10.1637/11089-041115-Reg.1> $<$ PMid:26629619>

Rosenfield R.N., Bielefeldt J., Rosenfield L.J., Taft S.J., Murphy R.K. \& Stewart A.C. 2002. Prevalence of Trichomonas gallinae in nestling Cooper's Hawks among three North American populations. Willson Bull. 114(1):145-147. <http://dx.doi.org/10.1676/0043-5643(2002)114[0145:POTGIN]2.0.CO;2>

Samour J.H., Bailey T.A. \& Cooper J.E. 1995. Trichomoniasis in birds of prey (order Falconiformes) in Bahrain. Vet. Rec. 136(14):358-362. <http:// dx.doi.org/10.1136/vr.136.14.358> <PMid:7610541>

Stabler R.M. 1941. The morphology of Trichomonas gallinae (Columbae). J. Morphol. 69(3):501-515. <http://dx.doi.org/10.1002/jmor.1050690306>

Tasca T. \& De Carli G.A. 1999. Prevalence of Trichomonas gallinae from the upper digestive tract of the common pigeon, Columba livia in the Southern Brazilian State, Rio Grande do Sul. Parasitol. Día 23(1/2):42-43. <http:// dx.doi.org/10.4067/S0716-07201999000100007>

Villanúa D., Höfle U., Pérez-Rodríguez L. \& Gortázar C. 2006. Trichomonas gallinae in wintering common wood pigeons Columba palumbus in Spain. Int. J. Avian Sci. 148(4):641-648. <http://dx.doi.org/10.1111/j.1474919X.2006.00561.x>

Work T.M. \& Hale J. 1996. Causes of owl mortality in Hawaii, 1992 to 1994. J. Wildl. Dis. 32(2):266-273. <http://dx.doi.org/10.7589/0090-355832.2.266> <PMid:8722264> 